\title{
"BRAIN PLASTICITY" AND STRESS
}

\author{
Marina Kostić
}

\begin{abstract}
The analysis of stress consequences, regarding its quality and intensity, is being done in a wide range, enveloping a spectrum of psycho-neuro-endocrinological, i.e., organic, cognitive, emotional and behavioral organism's response to the impact of stress. All the categories of organism's response occur due to an imbalance among the stressor on one side, and organism's resources available in the fight for overcoming stress, on the other. If psychological stability is not optimal, the disorder of organism's homeostasis will occur, physiological stability will be disturbed, psychosomatic symptoms and illnesses will appear as a result of ill health caused by stress, when "the target" can be any organ, system of organs or more systems in an organism. Human brain - the organ that differentiates us from all the other living beings by its complexity, monitors the whole organism as well as functions in all the fundamental fields: physical, physiological, psychological and cognitive, is considered to impact the response of the immune system to illness, and partly to a person's response to a medical treatment.

The aim of this paper was the analysis of the impact of stress on the brain as well as the consequences of stress, with the accent on the ability of brain known as "plasticity", and the possibilities of regeneration of damaged brain cells.

The paper describes the case of 36 year old patient, who, as a consequence of long lasting, chronic, intense stress, was diagnosed focal lesions in the white mass, during her first MRI scan of endocranium (in 2013). The patient was withdrawn from the stressful environment, and with the help of psychiatrist her psycho-social rehabilitation treatment started. By the check-ups in the following years, during medical monitoring, $(2014,2016)$ NAD reports of her MRI scan were found, taken on the same scanner and checked by the qualified radiologists.

The before mentioned medical case study supports the theory of brain plasticity, whereas it has to be pointed out that the findings about the embryonic development of the brain is of vital importance for understanding its ability to reorganize in response to outer stimuli, especially in the case of long lasting chronic stress or post traumatic states.
\end{abstract} Acta Medica Medianae 2020;59(2):72-80.

Key words: stress, brain, brain plasticity, regeneration

University of Niš, Faculty of Philosophy, Department of Psychology, Serbia

PhD student, index No 133

Contact: Marina Kostić

Ćirila i Metodija 2, 18000 Niš, Serbia

E-mail: markost79.mk@gmail.com

\section{Introduction: brain plasticity and stress}

Central nervous system (CNS) has a complex, hierarchical organization whose parts have specifically determined "ingerences" over different psycho-motor and other functions of the organism, wherefrom it is to organize and reorganize itself in different ways under the influence of experience, sensory stimulation, traumas... Thus, not all the brain parts can be easily modified and altered by experience, meaning that, not all the brain parts are equally plastic. Brain plasticity implies changes on the genetic and synaptic level, as well as on biological, chemical and physical levels, and it is worth mentioning that brain changes reflect themselves on the behavior as well. Environmental factors, personal experiences, and stress especially, lead to changes that will manifest in behaviour and might be evidence that a process of new learning has begun that will result in them. Schafer (1) settled the neurophysiologic hypothesis of stress caused behavior based on the study of decortified animal's activities, that points out that consequential behavior under stress is directly related to sub cortical processes. Neurological damage caused, for example, by trauma or a stroke, when weakened functions controlled by the damaged part of the brain must be re-learned, is also a "trigger" for new learning. It does not mean that any learning will lead to brain changes but that those will be forms 
manifested in behavior and everyday functioning of the organism.

Kolb and Gibb (2) state that after a brain injury, plastic changes happen, enabling recovery; these authors state three possibilities in that context - changes in organization of remaining circuits of the brain, the development of new circuits, including formation of new synapses and creation of new neural cells and glial cells that might replace some neural cells. Some changes in the morphology of neurons happen independently one from another, occasionally in opposite directions or some changes are interpreted as surrogate for others. Authors Robinson and Kolb (3) give an example: big behavioral changes occur under the influence of psychoactive drugs, but neural changes are localized in majority of cases on pre-frontal cortex and nucleus accumbens. Plasticity depends on the age. The logical assumption is that developing brain is more susceptible to change and more sensitive to influences of experience compared to the brain of adults and elderly people. However, it should be pointed out that not all the plasticities are equally good and useful. Although it is widely accepted that plastic brain changes improve motor and cognitive functions, they can in certain percentage of cases hinder some behavior. In this context, changes caused by medications, psychomotor stimuli are taken into consideration, as well as plasticity seen through the prism of pathological point of view (epilepsy, schizophrenia, dementia, etc.).

According to one of the sub-divisions (4) three main forms of plasticity are: synaptic plasticity, neurogenesis and functional compensational processing. Neurogenesis, related to creation and development of new neurons in the brain, is the source of many scientific disputes, research polemics and scepticism. Thesis on neuron production in the brain of adults imposes the question whether the neurons which die are replaced by new neurons.

Brain is a key organ in the process of stress: it determines what organism will experience as stress, it determines how the organism will deal with the stressors, it changes itself functionally and structurally - as a result of stress, simultaneously conrolling physiological, psychological, cognitive, emotional and behavioral reactions of the organism that are a response to stress. That two-way signalization, e.i., communication of the brain and the body is being done through short-term mecha-nisms that are adaptive (allostasis), and long-term that are maladaptive (allostatic load), which means that brain plasticity is the base for adjustment to stressful circumstances (5).

Neural brain circuits are responsible for behavioral and allodynamic system responses to stressors including hippocampus and amygdale, limbic brain structures, that send processed "signals" of experience to lower vegetative areas of the brain (hypothalamus and brainstem) and higher cortical areas as pre-frontal cortex (PFC); thus hippocampus, amygdale and PFC are considered coordinators between the behavior and allodynamic systems in reacting and confronting the outer and inner stimuli that pose a threat for organism's homeostasis; they play crucial role in cognition, emotions and impulse control, help the inter-pretation of stimuli, based on experience as threatening or otherwise influential (5).

Brain tissue samples of patients suffering from depression show that frontal cortex and hippocampus have glia cell loss and reduction in size of neuron body but not neuron loss (6). Although the reduction of prefrontal area occurs, scans show the increase of functional activity in the same area (6). It should be pointed out that prefrontal area and its functions with a healthy brain are susceptible to changes under influence of experience. The authors state a representative example of medical students whose cognitive flexibility changes and functional connectivity reduces due to exam stress, which is shown by MRI scan during the test, and all the symptoms disappear during the school break (6). The comparative analysis on rats points out that chronic stress leads to a reduction of cognitive flexibility and shrinking of the dendrites in PFC (6). It is interesting that the same stressors can have different impact on hippocampus and amygdale (5).

Prefrontal cortex is important for work memory and mechanisms of self-regulation and targeted behaviors, while structural and functional plasticity in this region is changed under the influence of behavioral experiences modifying neural circuits, thus directly impacting the function of the brain. Functions of dorsolateral PFC are important in the context of consideration of stress sensitivity, aging, and have a key role in the brain disorder development. As well as many other regions of the brain amygdale and PFC contain adrenal steroid receptors (6) and it is crucial to research the vulnerability and plasticity of PFC during the life cycle, since the results in this field will be of huge benefit in prevention, maintenance and enhancing of mental and physical health.

\section{The aim of the paper}

The aim of the paper was the analysis of the impact stress might have on brain and its consequences, with the emphasis on the feature of the brain known as "plasticity", as well as possibilities of regeneration of the damaged brain cells.

\section{Case study}

\section{Personal anamnesis}

Patient NN, 36 years old, a college graduate, permanently employed, divorced, one child, right handed, mother tongue Serbian. She has been living in Nis for 18 years. In her primary family she was the older child, her parents divorced after 27 years of marriage, when she was 28; family anamnesis burdened with malignant diseases: her father died of colon cancer when he was 56, and her four years younger brother died of acute lymphoblast leukemia in 2011 when he was 28, which was an extremely 
traumatic event for the patient, additionally burdened with subsequent marital problems.

The person in question is of very high aspirations and ambitions, which she could not realize during the marriage, especially during the last few years - which she explains by the loss of confidence during the time, "adrift and under the will of mentally stronger spouse", resulting in very frequent sense of depression, despair, dissatisfaction, neuromuscular tension, very frequent headaches and other psycho-somatic problems. During that period she has been treated for viral pericarditis, after that for stomach ulcer together with the colon damage; after her brother's death she has visited a psychiatrist periodically with the aim of psychological strengthening and improving the problem facing skills; the prescribed therapy by sedative (Bromazepam $1.5 \mathrm{mg}$ ) and antidepressant (Trittico retard 150 $\mathrm{mg}$ ) a minimal dose (1/3), has among other things, solved her problem with sleeping and insomnia.

She had tonsils and appendix removed by operation. Right handed.

\section{Examinations done and diagnostic results}

The first hospitalization was in February 2016 in the daily hospital for neurology because of the difficulties with the right eye as well as subjective feeling of uneasiness in the sense of pressure in the right eye, without any changes in the sharpness of sight. The symptoms mentioned have lasted for approximately two weeks before coming to the clinic, but the patient has not taken them too seriously, considering them temporary, although they have hindered her in doing her daily activities, especially reading and writing, and very frequently they have been followed by bodily instability and weakness. During the seven-day-stay at the daily hospital for neurology, she was given infusion ( $\mathrm{NaCl}$ with aminophylline), injections of OHB 12; and the analyses and research done led to the following conclusions:

- Psychological finding on admission implied preserved vigilance and orientation without visible psycho-pathological symptoms; somatic findings within normal limits, with neurological status. An eye exam showed no pathological signs, except indicated visus correction (Myopia, VOS $=-0.25, \mathrm{VOD}=-0.5$ ) dating from, according to the patient, previous 10 years ago. Lab results on admission were NAD. It should be pointed out that lab results and tests were $N A D$, all parameters within limited values, during all MRI scans and hospitalization.

- The first set EP (VEP, AEP, SSEP) done in 2013 was NAD; the last test (2016) was without any significant asymmetry on all modalities, NAD.

- Neuropsychological testing showed exceptional actual level of intelligence, with far better achievements in relation to the testing performed two years earlier. MMPI questionnaire showed a profile with minimum rise in depression scales as the fall of willful impulses.

- The conclusion from MRI brain scan, third in the period of three years, showed initial reductive parenchyma changes on convexity parietally bilaterally, and other endocranium structures NAD.

Based on the anamnestic data, somatic and neurological findings clinical features presented possible retrobulbar neuritis of the right eye, and the control neuroimaging (brain MRI scan) and neurophysiologic diagnostics did not show the existence of structural lesions and functional disturbances of the brain parenchyma.

Within the context of this paper related to the brain plasticity, it was crucial to do a comparative analysis of MRI endocranium scans that were, except for the last one in 2016, abovementioned, done annually, in 2013 and 2014.

After MRI scan done in 2013 and the conclusion which indicated that lesions were in the form of demyelization, on the neurological level (EP scans, neuropsychological testing, etc.) it was clarified that there was no potential possibility of multiple sclerosis. However, in relation to the newest, abovementioned neuropsychological testing, the conclusion drawn at that moment was that the actual level of intelligence matched higher to above average level of intelligence, without quantitative determiners of attention disorder, but with evident significant flow of extreme anxiety, that resulted from willing avoidance of focusing on the stimuli. The recommendation was to see a psychiatrist and retest in 6 months, which was done a year later. It should be pointed out that MRI scans of the head were done on the same scanner in the Clinical Centre Niš.

\section{3 scan}

On the day of 01.11.2013, T1W and T2W/FLAIR axial, T1W and T2W sagittal and T2W coronary tomograms through the brain were done. The scan showed two discrete T2W/FLAIR hypersignal changes, by the atrium of the right lateral chamber as well as in the frontal sub cortex on the same side. A change of the same characteristics existed on the left hemisphere of the cerebellum, without lesions manifested in the brainstem and medulla oblongata. All the other structures tested were without pathological changes, new substances, or significant inflammatory manifestations. The conclusion of the radiologist was, therefore, that there were several focal lesions in the white mass that might have had the form of demyelization, with the recommendation of further control (Figure 1). 

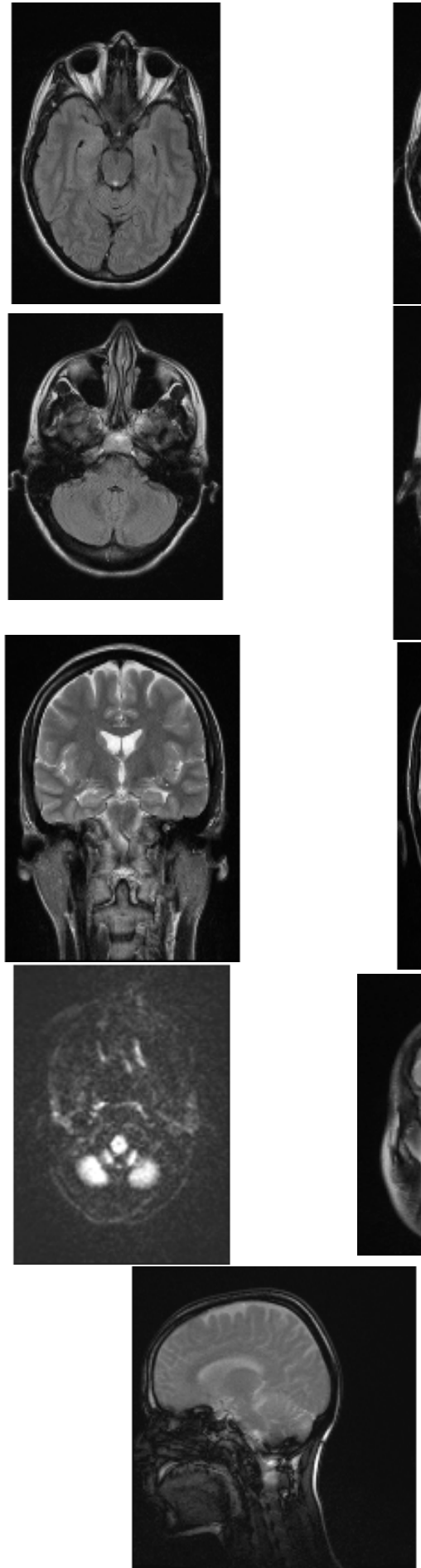
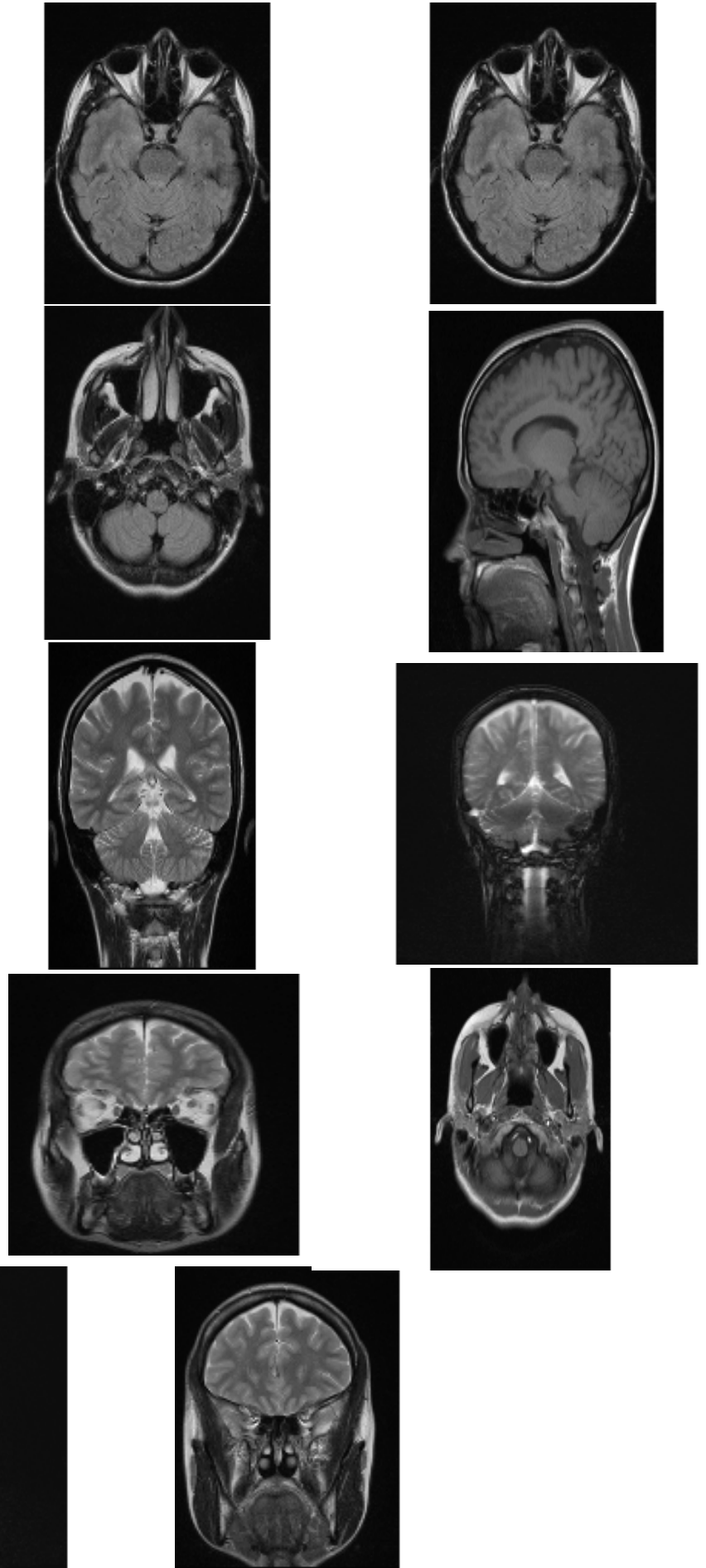

Figure 1. MRI neuroimaging in axial, sagittal and coronary plane

\section{4 scan}

On the day of 17.10.2014, T1W and T2W/FLAIR axial, T1W and T2W sagittal and T2W coronary tomograms through the brain were done, and compared to the previous above described MRI scan from 2013. In the frontal sub cortex on the right side there were two discrete T2W/FLAIR hypersignal changes, matching widened perivascular spaces. There were no lesions of brainstem, medulla 
oblongata and cerebellum. All the other structures tested were without pathological changes, new substances, or significant inflammatory manifestations.
The conclusion of the radiologist that time was NAD (Figure 2).
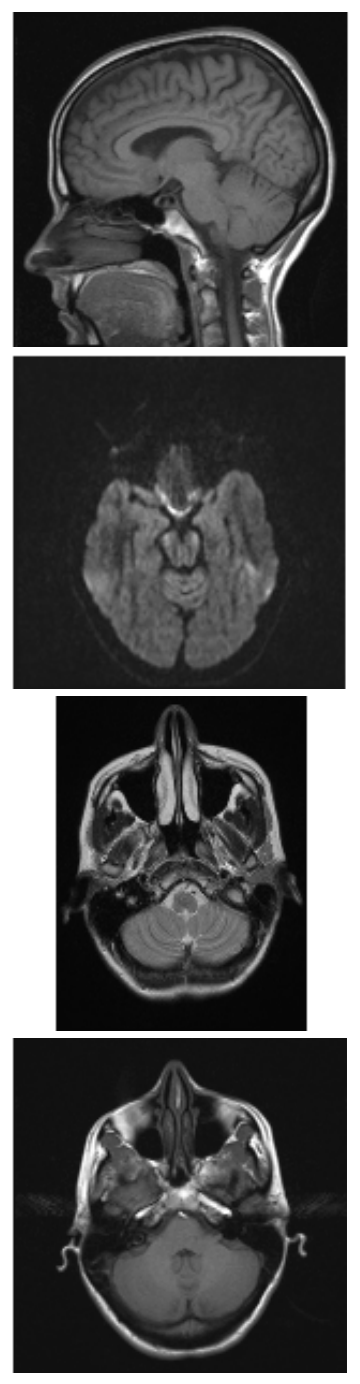
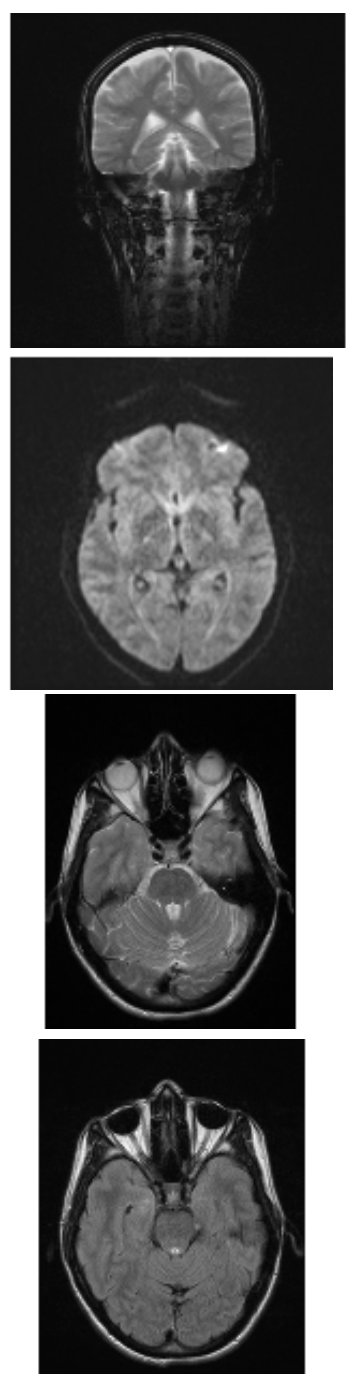
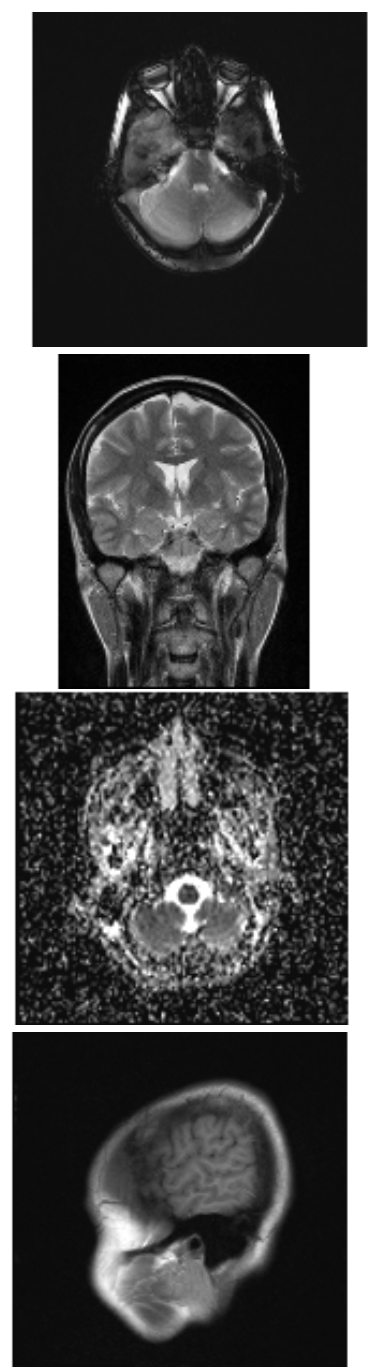

Figure 2. MRI neuroimaging in axial, sagittal and coronary plane

\section{6 scan}

On the day of 17.02.2016 MRI scan of endocranium was done by standard procedure and it showed symmetrically wider peripheral CSF spaces; brain parenchyma of the proper morphology and signal intensity without focal lesions, no pathological changes or signs of inflammation. Mediosagital structures, ventricular system, brainstem and cerebellum of the proper content, structure and size. The conclusion - the initial reductive parenchyma changes in the convexity parietally bilaterally, with other endocranium structures NAD (Figure 3 ). 

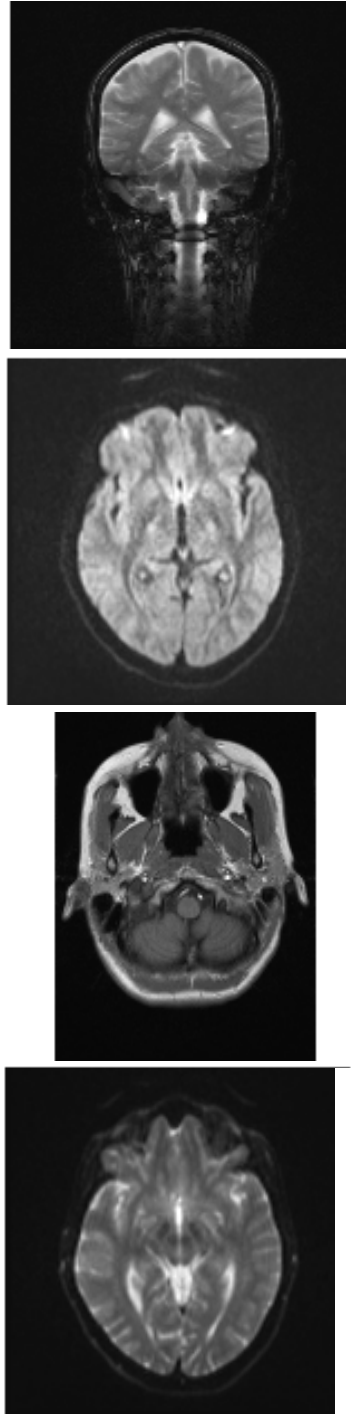
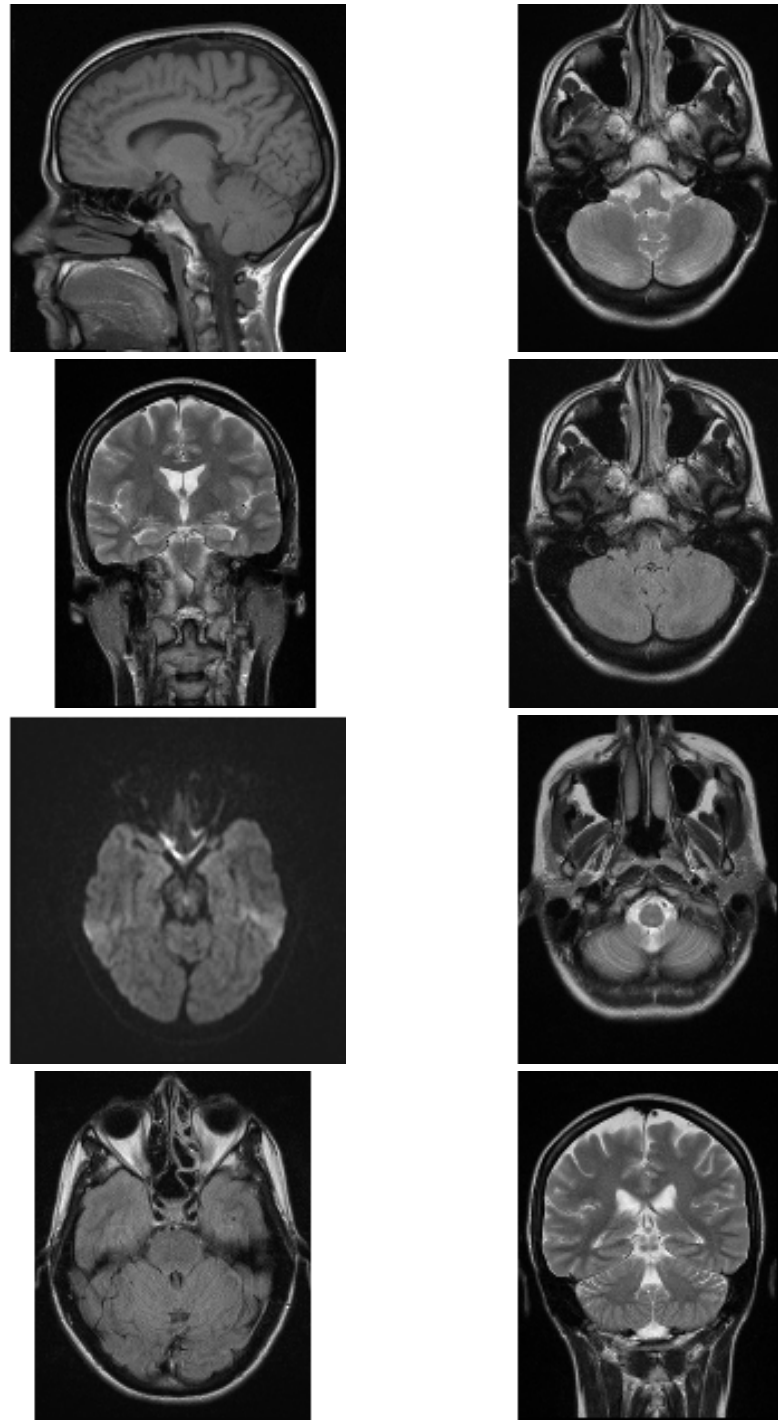
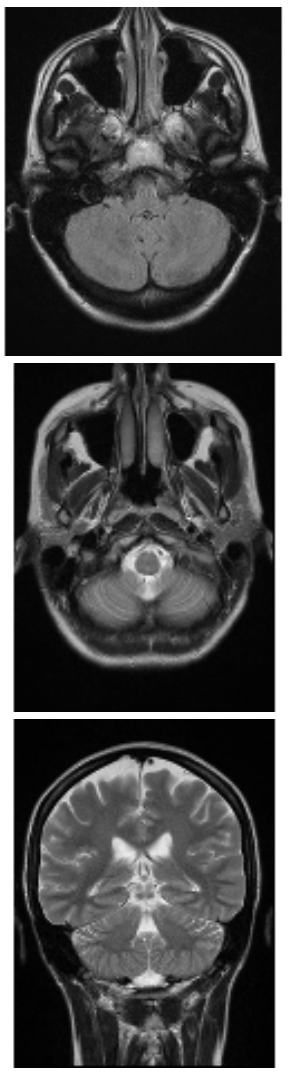

Figure 3. MRI neuroimaging in axial, sagittal and coronary plane

\section{Discussion}

Having in mind the plasticities described in the literature (synaptic plasticity, neurogenesis and compensatory plasticity) and their characteristics, the theoretical basis of the analysis of this topic and the results of contemporary medical research which go in its favour and support it with examples, the case of the patient Jane Doe (36 years old) can also be put in the abovementioned complex frame of scientific discussions on brain function and its role in coordination between the impact of the stressors on one hand and organism responses on the other.

It has been concluded that levels of plasticity are different in various ages and that interactions between different types of plasticities caused by activity, i.e., surrounding stimuli and the age of the patient are of crucial importance for understanding the decline of the level of intellectual and mental capacities the person faces as a consequence of the effects of those surrounding stimuli in certain parts of the brain. The consequences can be degenerative processes or the processes of compensation of "endangered" neurons. Neurons have their extensions and form complex neural networks using them, and each damage means its "loosening", after which the network will naturally tend to regenerate or reorganize, that is evident in this case study. Timely rehabilitation establishes proper neural circuits and function of the damaged areas of the CNS. With aging, the plasticity is weakened and decreased, but still exists - not only during the normal functioning period but also in the pathological states; it is considered that the building, reorganization and regeneration of the connections between neurons, that will make up for "disintegrated" neurons, is of the core importance (7). There is a qualitative difference of the brain changes occurring as a consequence of the completely same experience but at different stages of life. Considering the fact that the 
factors plasticity depends on are gender differences, aging and mood disorders (6), "accumulated" stress experiences can lead to brain neuron damage and the reduction of the plasticity, and in this paper it is documented that by timely pharmacological and psychological actions, intervention, strengthening as well as isolating from stressful environment, might lead to regeneration and recovery of the individual. Brain processes, i.e., plasticity depend on surrounding stimuli as well as internal environment by the organism itself, thus dictating allostasis that is the core of its homeostasis. Allostatic mechanisms are crucial in sudden stressful situations, but their impact is prolonged, they influence negatively both mental and physical health primarily because of the negative effects to the brain plasticity. Both mechanisms are connected to the concept of expectations and evaluation of the stressor, prediction, care and anxiety and cognitive preparation (5). Cognitive preparation has, in this case, in the long run, brought about positive effects in the sense of stressor evaluation and adaptation of the patient which resulted in the recovery on every level of functioning. At this point, it should be emphasized that not all stressful situations are negative; some forms of mild stress are necessary for normal, successful development of the individual (8).

What is the relationship between the brain plasticity and the duration of surrounding stimuli? Some changes occur under the influence of the stimuli for a short period of time, some are influenced by stimuli for a longer period of time, whereas other neurons have not undergone any other change or the course of changes has been reversed. Plasticity refers to all the ways the brain changes, including the changes followed by the damage of the functions and changes in behavior. Authors Kolb and Gibb (2) consider that changes in the brain can be seen in many levels of analysis, and result in changes in behavior, and that there are many ways for them to be explored, from global measuring of brain activity to in vivo scan. Thus, when it comes to changes in behavior, the patient was completely aware of them but often felt personal "helplessness" to resist them due to locus control disorder and disturbances which became frequent in the area of cognitive functions: memory, attention, concentration, sometimes even physical orientation. Plastic changes initiated by experience do not occur with equal probability in all parts of the brain, but depending on the traumatic influences, the occurrence of synaptic changes in different brain hemispheres has to be analyzed. Reaction of the organism to stress is always the same - adjustment. However, when it comes to plasticity it should be pointed out that plasticity is the basis of adjustment in stressful circumstances but it can also be the base for pathophysiological reactions of the organism to stressful circumstances, with direct influence on a person's mental and physical health (5), as in the case analyzed. During the period of two and a half years of monitoring of the patient's health, besides the before mentioned comparison of medical findings, it is of high importance to point out that, during the monitoring, the patient, after the divorce (the beginning of the monitoring period), at her own initiative, with support and encouragement of the psychologist and the psychiatrist, as well as support found in professional medical literature, positive psychology and professional literature, has in many ways changed the way of thinking, style and way of life, and has carried out changes and her own self actualization in all the spheres of life (hobby, professional training, promotions at work, further education, sport and recreation...).

Extreme stressful experiences have functionally relevant effects on the dendrites and the number of neurons, and it is not only the influence on cognitive functions but also on neuro-endocrinal, autonomous functions, emotional regulation, cognitive processes, and patterns of behavior (5). Through the prism of this paper, along with the comparative analysis of MRI scans, there are significant differences in the results of neuropsychological tests (18.12.2013. and 18.02.2016.) which show significant improvement of general intellectual capacities all the parameters (global, verbal and non-verbal IQ) and actual level that initially implied high to above average level, and afterwards to - above average intelligence. Although there were not any quantitative markers of attention disorder, mnestic data initially implied influence of highly expressed testable and general anxiety which resulted in willing avoidance of focusing on a certain type of stimuli. The fact that the patient at the very beginning of the monitoring was aware of the drastic decline of her intellectual capacities and abilities, anxiety that prevented her from daily functioning and mnestic disturbances, is intriguing - which she has blamed on long-term effect of the intense, chronic stress. Changing her life circumstances, surroundings, introducing positive stimuli and willing and intentional isolation from the stressful life context and the influence of stressful stimuli of any kind, positive changes occurred which have been noted on organic and neuro psychological level of functioning, which can be subsumed under the effects of brain characteristic that is the topic of this paper - its plasticity. It resulted in the improvement of general health, psychological stability, and readiness to take responsibility and face problems.

It can be concluded that the experience shapes the brain plasticity, but it raises the question whether it is possible to influence it by introducing focused system intervention, and whether there are ways for keeping elasticity and plasticity of prefrontal part in spite of aging. Many research and studies confirm the thesis by their empirical findings: it is possible to intervene and change "the architecture" of the brain, improve the cognitive functions and self regulatory behavior. As an example, cognitive training is a good way of stimulating and activating of brain plasticity since it provides systematic drill necessary for setting up of new and strengthening of the existing neural connections in the neural network. The mature brain has greater ability for plasticity than thought before, which turns out to be very significant point for planning of behavioral and pharmacological treatment in the future. 


\section{Conclusion}

Isolation from stressful life context and influence of stressful stimuli, positive changes in the functioning and achievement of personal ambitions and aspirations, that is, general satisfaction with life and self satisfaction are important factors which can influence on overcoming the consequences of long term, chronic stress the person has been exposed to, as well as its gradual elimination. The brain can be considered as an organ whose key role is in the process which defines what the organism will regard as stress, and the way the organism will handle the stressors regarding the adaptation and restoration of its homeostasis and alostasis. The before mentioned case study gives us the right to conclude that the brain is the organ susceptible to functional and structural changes as a result of stress, as well as confirming the fact that the same organ, at the same time controls physiological, psychological, cognitive, emotional and behavioral reactions of the organism as a response to stress. Based on all above mentioned, we can say that brain's plasticity explains the evident resulting changes seen on patient's MRI scans of endocranium, as well as significant improvements in achievements noticed during the neuropsychological tests. This and similar cases, are pre condition for the progress of neuroscience and set up the task and obligation for the experts to use present findings and new discoveries on the development of the nervous system to better understand certain illnesses and their origin, beginning, and treatment.

\section{Possible weak points of the research}

Due to complexity of the brain and influence of many factors, both endogenous and exogenous, it should be pointed out that these brain changes can be caused by other factors, not only stressful ones, considering the fact that the patient has had serious viral et as well as positive family burden on leukemic diseases. In that way, one cannot exclude the possibility that, besides the psychological stressors some organic CNS diseases were in action as well. We should also have in mind that the MRI scan results were not analyzed by the same radiologist each time, but by three different radiologists, inter subjective compatibility must be considered too, with respect to interpersonal differences in observation, findings and interpretation of the scan results.

References

1. Nešić, M. (2005): Psihoneuroendokrinoimunologija stresa, Univerzitet u Nišu, Medicinski fakultet.

2. Kolb, B., Gibb R. Brain Plasticity and Behaviour in the Developing Brain. J Can Acad Child Adolesc Psychiatry 2011;20(4): 265-76. [CrossRef] [PubMed]

3. Robinson TE, Kolb B. Structural plasticity associated with exposure to drugs of abuse. Neuropharmacology 2004;47 (Suppl)1:33-46. [CrossRef] [PubMed]

4. Kolb B, Muhammad A, Gibb R. Searching for factors underlying cerebral plasticity in the normal and injured brain. Journal of Communication Disorders 2010;44 (5):503-14. [CrossRef] [PubMed]

5. McEwen BS, Gianaros P. Stress- and allostasis-induced brain plasticity, Annu Rev Med 2011;62:43145. [CrossRef] [PubMed]
6. McEwen BS, Morrison JH. The Brain on Stress: Vulnerability and Plasticity of the prefrontal cortex over the life course. Neuron 2013;79:16-29. [CrossRef] [PubMed]

7. Gschwend G. Neurofiziološki temelji razvojne rehabilitacije, Interni materijal za kolegij „Rana rehabilitacija", Edukacijsko-rehabilitacijski fakultet, Sveučilište u Zagrebu; 1998.

8. Obrenovic J. Modeli stresa In: Nesic M. Psihoneuroendokrinoimunologija stresa. Nis (SRB): Medicinski fakultet Niš; 2005. 


\title{
Originalni rad
}

UDC: 159.944.4:616.831

doi: $10.5633 / a m m .2020 .0210$

\section{"PLASTIČNOST MOZGA" I STRES}

\author{
Marina Kostić \\ Univerzitet u Nišu, Filozofski fakultet, Katedra za psihologiju, Niš, Srbija \\ Student doktorskih studija, index No. 133 \\ Kontakt: Marina Kostić \\ Ćirila i Metodija 2, 18000 Niš, Srbija \\ E-mail: markost79.mk@gmail.com
}

Analiza posledica stresa, s obzirom na njegov kvalitet i intenzitet, vrši se $u$ širokom okviru, koji obuhvata spektar psihoneuroendokrinoloških, odnosno organskih, kognitivnih, emotivnih i bihevioralnih odgovora organizma na delovanje stresora. Sve kategorije odgovora organizma nastaju zbog disbalansa između stresora, sa jedne strane, i resursa organizma raspoloživih u borbi za prevladavanje stresa. Ako psihološka stabilnost nije na optimalnom nivou, doći će do poremećaja homeostaze organizma, narušavanja fiziološke stabilnosti i javljanja psihosomatskih simptoma i bolesti kao posledice stresom narušenog zdravstvenog stanja osobe, kada "meta" može biti bilo koji organ, sistem organa ili više sistema u organizmu. Ljudski mozak, organ koji nas svojom složenošću razlikuje od svih ostalih živih bića, ima nadzor nad celim organizmom i svim funkcijama, na svim fundamentalnim poljima: fizičkom, fiziološkom, psihološkom i kognitivnom, smatra se da utiče na odgovor imunološkog sistema na bolest, pa delimično i na odgovor pojedinca na lečenje.

Cilj rada je analiza uticaja koje stres može imati na mozak i posledica stresa, sa akcentom na svojstvo mozga poznato kao "plastičnost", kao i mogućnosti regeneracije oštećenih ćelija mozga.

$\mathrm{U}$ radu je prikazan slučaj bolesnice stare 36 godina, kojoj su, kao posledica uticaja višegodišnjeg, hroničnog i intenzivnog stresa prvim urađenim MR pregledom endokranijuma (2013. godine) konstatovane fokalne lezije u beloj masi. Bolesnica je povučena iz stresogenog okruženja i uključivanjem psihijatra otpočet je psihosocijalni rehabilitacioni tretman. KontroInim pregledima, koji su narednih godina usledili tokom medicinskog praćenja (od 2014. do 2016.), konstantovani su uredni MR nalazi pregleda glave, snimljeni na istom aparatu i pregledani od strane kvalifikovanih radiologa.

Navedeni prikaz bolesnice govori u prilog potvrdi teorije o "plastičnosti mozga", pri čemu treba naglasiti da su saznanja o embrionalnom razvoju mozga od osnovne važnosti za razumevanje njegove sposobnosti reorganizacije u odgovoru na spoljašnje nadražaje, naročito ako se govori o dugogodišnjem, hroničnom stresu ili o periodu posle povrede.

Acta Medica Medianae 2020;59(2):72-80.

Ključne reči: stres, mozak, "plastičnost mozga", regeneracija 